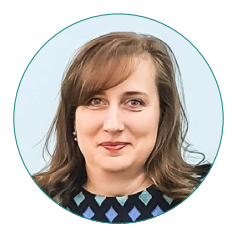

Е. В. Щанина

\title{
ПРАКТИКИ ПОВЕДЕНИЯ ПОЖИЛЫХ ЛЮДЕЙ, НАПРАВЛЕННЫЕ НА ПОВЫШЕНИЕ СВОЕГО БЛАГОСОСТОЯНИЯ, В СОВРЕМЕННОМ РОССИЙСКОМ ОБЩЕСТВЕ
}

\section{Правильная ссылка на статью:}

Щанина Е.В. Практики поведения пожилых людей, направленные на повышение своего благосостояния, в современном российском обществе // Мониторинг общественного мнения: экономические и социальные перемены. 2021. № 2. C. 138-161. https:// doi.org/10.14515/monitoring.2021.2.1702.

\section{For citation:}

Shchanina E. V. (2021) Behavioral Practices of Senior Citizens Aimed at Improving Their WellBeing in Contemporary Russia. Monitoring of Public Opinion: Economic and Social Changes. No. 2. P. 138-161. https://doi.org/10.14515/monitoring.2021.2.1702. (In Russ.) 
ПРАКТИКИ ПОВЕДЕНИЯ ПОЖИЛЫХ ЛЮДЕЙ, НАПРАВЛЕННЫЕ НА ПОВЫШЕНИЕ СВОЕГО БЛАГОСОСТОЯНИЯ, В СОВРЕМЕННОМ РОССИЙСКОМ ОБЩЕСТВЕ

ЩАНИНА Екатерина Владимировна доктор социологических наук, доцент, профессор кафедры "Социология и управление персоналом", Пензенский государственный университет, Пенза, Россия

E-MAIL: shchanina@mail.ru

https://orcid.org/0000-0002-6834-1886

Аннотация. Актуальность исследования обусловлена возрастающей потребностью в решении социальноэкономических проблем, связанных с увеличением доли и численности пожилых людей, а также с соответствующими изменениями в социальной структуре российского социума, в системах производства, распределения и потребления, что в итоге влияет на положение всех социальных групп и слоев. Цель исследования - выявить практики поведения пожилых людей, направленные на повышение своего благосостояния. Эмпирическая часть статьи основана на данных авторских межрегиональных исследований, полученных в ходе анкетных опросов пенсионеров - «Направления социальной активности пожилых людей в процессе социальной адаптации" (20182019 гг.) и работодателей - «Востребованность представителей старшего поколения на рынке труда (2018 г.). обобщив теоретико-методологические подходы, рассматривающие социальное поведение пожилых людей в современных условиях, автор типологизирует практики поведения пенсионеров в зависимости от характера социальной активности. На основе проведенных
BEHAVIORAL PRACTICES OF SENIOR CITIZENS AIMED AT IMPROVING THEIR WELL-BEING IN CONTEMPORARY RUSSIA

Ekaterina V. SHCHANINA ${ }^{1}-D r$. Sci. (Soc.), Professor, Department of Sociology and Human Resource Management E-MAIL: shchanina@mail.ru https://orcid.org/0000-0002-6834-1886

\footnotetext{
${ }^{1}$ Penza State University, Penza, Russia
}

Abstract. The topicality of the study is due to new socio-economic problems associated with an increase in the proportion and number of senior citizens in Russia. This causes changes in the social structure of Russian society, as well as in its systems of production, distribution, and consumption, and as a result - affects the position of all social groups and strata. The aim of the study is to identify the behavioral practices of the senior citizens aimed at improving their well-being. The empirical part of the article is based on data from interregional surveys conducted by the author: "Lines of social activity of the elderly people in the process of their social adaptation" (a survey of the pensioners in 20182019) and "Demand for representatives of the older generation in the labor market" (a survey of the employers in 2018). The author summarizes theoretical and methodological approaches that consider the social behavior of elderly people in current conditions, and typologizes the practices of the behavior of pensioners, depending on the nature of social activity. Based on the research carried out and the secondary analysis of its results, the author draws the following conclusions: First, the most common practices aimed 
исследований и вторичного анализа их результатов сделаны следующие выводы: во-первых, к числу наиболее распространенных практик, направленных на повышение своего благосостояния, помимо получения пенсии по достижении возраста, относятся трудовая деятельность, финансовое поведение, ведение натурального хозяйства с целью получения дополнительного дохода. Во-вторых, в соответствии с предложенной типологией, 65,9\% пожилых людей выбирают и реализуют активный тип практик поведения, а 34,1\% - пассивный. В-третьих, уровень активности пенсионеров неодинаков и определяется количеством одновременно выбранных и реализуемых практик. В-четвертых, выбор и реализация практик поведения пожилых людей, направленных на повышение своего благосостояния, происходят под влиянием как социальной среды, так и личностных характеристик.

Ключевые слова: пожилые люди, социальное поведение, практики поведения, социальная эксклюзия пожилых людей, социальная активность пожилых людей, социальный риск, социальная адаптация at improving the seniors' well-being include (in addition to receiving a pension): work, financial behavior, subsistence farming for the purpose of supplementary income. Second, in accordance with the proposed typology, $65.9 \%$ of the seniors choose and implement an active type of behavioral practice, whilst only $34.1 \%$ - a passive one. Third, the level of activity of the pensioners is different. It is determined by the number of simultaneously selected and implemented practices. Fourth, the choice and implementation of behavioral practices of the seniors aimed at improving their well-being are influenced by both the social environment and personal characteristics.

Keywords: senior citizens, social behavior, behavioral practicies, social exclusion of elderly people, social activity of elderly people, social risk, social adaptation

\section{Введение}

В условиях современного "стареющего" общества проблема выбора и реализации практик поведения, ориентированных на сохранение и поддержание достигнутого уровня благосостояния в пожилом возрасте, становится все актуальнее в связи с непростыми социально-экономическими условиями, пенсионной реформой, модернизацией системы здравоохранения и социальной защиты. Данные обстоятельства заставляют тех, чей возраст приближается к границам пенсионного, тщательнее подходить к вопросу выбора практик социальной адаптации, позволяющих менее болезненно обеспечить переход в разряд пожилых людей, сформировать комфортную социальную среду жизнедеятельности и способствовать интеграции в современное российское общество в новом статусе. Следует подчеркнуть, что рост интегрированности людей этой возрастной кате- 
гории в экономическую и общественную жизнь в условиях продолжающегося старения населения и повышения демографической нагрузки рассматривается уже как объективная необходимость, поскольку определенная часть пожилых людей обладает ценными профессиональными компетенциями, востребованными в научных, медицинских, проектно-конструкторских организациях, где необходимы сохранение и передача накопленного опыта. Однако это достаточно сложная проблема, которой, как правило, препятствуют сложившиеся негативные стереотипы, дискриминация людей старшего возраста и отсутствие способов эффективного использования человеческого потенциала. Разработка и реализация комплекса мероприятий, направленных на решение этих проблем, должны, с одной стороны, способствовать устойчивому социально-экономическому развитию страны, а с другой стороны, создать предпосылки для использования человеческого потенциала пожилых людей и тем самым обеспечить им достойный уровень и качество жизни. Эффективность данных мероприятий во многом зависит от того, насколько при их разработке и реализации учтены социально-демографические особенности данной социальной группы.

На развитие и реализацию потенциала человека, увеличение продолжительности жизни, трансформацию восприятия старения направлена политика активного долголетия. По определению Всемирной организации здравоохранения (В03), впервые сформулированного в 2002 г. в Рамочной стратегии активного долголетия В03, активное долголетие представляет собой процесс оптимизации возможностей в области здоровья, участия и безопасности с целью повысить качество жизни по мере старения. Выделены три основных компонента: «здоровье», подразумевающее физическое, психологическое, социальное благополучие; “участие» - интеграция в социальную, экономическую, культурную, гражданскую и духовную сферы общества через активное участие в мероприятиях; "безопасность" - создание безопасной и надежный среды, гарантирующей стабильный доход и, если это применимо, оплачиваемую занятость [World Healh Organisation, 2002].

Основные положения концепции активного долголетия, а также результаты авторских межрегиональных исследований позволяют акцентировать внимание на том, что пожилые люди способны вносить значимый вклад в повышение качества своей жизни и жизни окружающих, а не только являются пассивными получателями пенсий, социальной и медицинской помощи.

Учитывая, что с наступлением пенсионного возраста для большинства граждан нашей страны проблема сохранения и поддержания достигнутого уровня благосостояния выходит на первый план, в статье анализируются практики поведения пожилых людей, направленные на повышение своего благосостояния в современном российском обществе, выявляются факторы, определяющие выбор и реализацию соответствующих практик.

Необходимость исследования практик социального поведения пожилых людей обосновывается повышением пенсионного возраста в России, осуществляемым в рамках реформирования пенсионной системы, что вызвало негативную социальную реакцию общества. Следует отметить, что привычный для населения России пенсионный возраст для отдельных категорий работающих граждан был установлен в 1932 г., в 1967 г. были определены границы пенсионного возраста, 
дающего право на назначение и получение пенсии по старости, и вплоть до 2019 г. эти параметры не пересматривались. Поскольку на протяжении достаточно длительного периода пенсионный возраст не менялся, в сознании россиян сформировалось четкое представление о критериях пенсионного обеспечения, учитывая которые, они планируют свой образ жизни и реализуют практики поведения.

Внимание сфокусировано на нескольких ключевых моментах: выбор и реализация пожилыми людьми практик поведения осуществляется одновременно с процессом их социальной адаптации, так как наступление старшего возраста символизирует переход человека из одной социальной группы в другую; уровень интегрированности пожилого человека в современный социум находится в прямой зависимости от результатов этих процессов; данные процессы реализуются в сложных социально-экономических условиях современного российского общества, характеризуемого как общество риска.

В связи с этим актуальность исследования практик поведения пожилых людей, направленных на повышение своего благосостояния, в современном обществе не вызывает сомнений в силу теоретической и практической значимости.

\section{Материалы и методы}

Теоретическую базу исследования составили концепции классиков социологической мысли, научные положения и выводы, сформулированные в трудах современных отечественных и зарубежных социологов, исследующих проблемы пожилых людей.

Эмпирической основой анализа выступают данные межрегиональных количественных исследований, полученные в 2018-2019 гг. в ходе анкетных опросов пенсионеров «Направления социальной активности пожилых людей в процессе социальной адаптации" (выборка анкетного опроса репрезентирует население старше 60 лет Пензенской и Саратовской областей и Республики Татарстан, отсортированное по типу населенного пункта, возрасту, полу и образованию; объем выборочной совокупности составил $N=1120)$ и работодателей «Востребованность представителей старшего поколения на рынке труда» (выборка анкетного опроса репрезентирует работодателей Пензенской и Саратовской областей и Республики Татарстан, отсортированных по форме собственности и сфере деятельности предприятия; объем выборочной совокупности оставил $N=268$ ).

\section{Обзор литературы}

Существование и развитие современного российского общества все больше описывается с использованием таких понятий, как турбулентность, неопределенность, непредсказуемость и рискогенность. О.Н. Яницкий подчеркивает, что "турбулентность в действительности означает крайнюю степень нестабильности мировой экономической и политической системы, когда вероятность достижения точки ее бифуркации и/или слома очень высока. „Турбулентность“- это всепроникающий риск ее деградации и разрушения вследствие нового этапа передела мира и его ресурсов, непримиримого конфликта культур, отягощенного локальными конфликтами и войнами" [Яницкий, 2011: 158]. Все это происходит в связи с процессами поляризации общества, высокими темпами изменений, глобали- 
зацией, атомизацией, индивидуализацией и т.д. В свою очередь происходящие в обществе процессы вызывают различные реакции социальных групп и акторов, которые проявляются в выборе и реализации практик социального поведения: одни стараются сохранить привычный образ жизни, ориентируясь на традиции, что приводит к отставанию от современности; другие "живут по обстоятельствам", избегая решительных действий, превращаясь в социальных иждивенцев; третьи пытаются самостоятельно найти новые способы решения возникающих жизненных проблем.

Очевидно, что в современных условиях для предотвращения ситуации попадания в первые две группы акторам необходимо корректировать набор практик социального поведения, предопределенных культурой, традициями, ценностями, нормами и опытом предыдущих исторических и социальных этапов развития общества.

Следует также отметить, что в условиях неопределенности и рискогенности необходимо формировать такой набор практик социального поведения (уместно применить понятие "веер стратегий" [Швери, 1996], предложенное Дж. Коулменом в теории рационального выбора), при помощи которого уменьшается зависимость от многих внешних факторов и повышается эффективность социального взаимодействия (появляются бо́льшие возможности для адаптации, самореализации, раскрытия своего внутреннего потенциала).

В социологической науке можно выделить несколько подходов к исследованию социального поведения, среди которых: рассматривающие социальное поведение как деятельность (Г. М. Андреева, И. С. Кон, Н. Ф. Наумова, М. С. Качан, С. С. Батенин, А. Н. Леонтьев, Б. Г. Ананьев и др.); социологическая теория обмена (Дж. Хомас, М. Мосс, К. Леви-Стросс); теория символического интеракционизма (Ч. Кули, Г. Мид, Г. Блумер); социальное поведение как непрерывный процесс взаимодействия людей (П. Сорокин); теория социального действия Т. Парсонса; девиантное поведение (Э. Дюркгейм, Р. Мертон, Р. Дарендорф и др.).

Следует подчеркнуть, что социальное поведение - фундаментальная категория социологической теории, используемая при изучении внешне выраженного взаимодействия индивида, группы индивидов, общества в целом с окружающей природой и социальной средой. Согласно М. Веберу, сходство в социальном поведении объясняется тем, что данный тип поведения в значительной степени соответствует индивидуальным интересам индивида, а не ориентации на признанные значимыми социальные нормы и ценности. Чем более целерационально поведение индивидов, тем больше сходства в нем можно найти. Это основа появления устойчивого единообразия моделей поведения конкретной социальной группы [Вебер, 1990].

Изменения в социально-демографической структуре современного российского общества, связанные с увеличением доли пожилых людей в составе населения, и возникающие на этом фоне социальные проблемы актуализируют потребность в исследовании практик поведения пенсионеров и уровня их социальной активности в современном российском обществе. $K$ настоящему времени накоплен значительный объем научно-теоретических и прикладных исследований социальной группы пожилых людей [Максимова и др., 2015; Саралиева, Балабанов, 
2003; Холостова, 1999], образа и стиля жизни пожилых людей [Елютина, 2017; Корнилова, 2017; Савинов, Кочетков, 2017; Щукина 2004], проблем адаптации к современным условиям [Кошарная, Щанина, 2019; Щанина, 2017], стратегий социального поведения [Григорьева, Парфенова, Петухова, 2018; Козлова, Краснова, 2015; Максимова, Старчикова, 2009; Неваева, Максимова, 2016; Саралиева, Балабанов, 2003] и т.д. Однако трансформационные процессы, проходящие во всех сферах жизни общества, побуждают исследовать потребности, мотивы, практики поведения пожилых людей в современном обществе с целью создания комфортных условий для самореализации, повышения качества жизни и интеграции в современный социум.

Наступление пенсионного возраста - определенный рубеж, связанный с конкретной жизненной ситуацией, характеризующейся совокупностью значимых для каждого человека событий и соответствующих им потребностей, ценностей, представлений, оказывающих влияние на поведение и мировоззрение. Поэтому с выходом на пенсию для полноценного функционирования в обществе человеку необходимо менять свое поведение, проявляя социальную активность.

Для пожилых людей социальная активность - необходимое условие активного долголетия. Многие страны рассматривают активное долголетие как цель социально-экономической политики в сложившихся социально-демографических условиях. Концепция активного долголетия позволяет изменить приоритеты в части социальных реформ, сменить фокус в отношении к старению.

Границы социальной активности пенсионеров определяются социальной средой, представляющей собой систему ценностей, традиций, норм и правил поведения, регулирующих жизнедеятельность людей. О необходимости исследования факторов, влияющих на выбор пожилыми людьми практик социального поведения, свидетельствуют работы известных российских ученых [Григорьева и др., 2015; Елютина, Болотов, 2017; Козлова, Краснова, 2015; Максимова, Старчикова, 2009; Неваева, Максимова, 2016; Тощенко, 2016].

Выбор и реализация пожилыми людьми практик социального поведения зависят от процессов и явлений, происходящих в обществе, деятельности социальных институтов и организаций, особенностей взаимодействия индивида с социальной средой, ценностей и ценностных ориентаций индивида, принятых в обществе традиций, норм и правил, индивидуальных особенностей человека и т. п. - следовательно, от факторов, которые условно можно разделить в две группы:

- личностные факторы: пол, возраст, здоровье, социально-личностные качества, психологические черты характера, система ценностей, ценностные ориентации, потребности, интересы, убеждения, мировоззрение, отношение к окружающей реальности, умение и желание адаптироваться к социальной среде, людям, группам, общностям, уровень доверия по отношению к окружающей социальной среде (как на межличностном, так и на институциональном уровне);

- факторы социальной среды: место жительства, существующие стереотипы в отношении людей старшего возраста, социальная политика, доступность необходимых, а не навязываемых социальных услуг, пенсионное обеспечение, востребованность обществом накопленного социального, профессионального, интеллектуального, человеческого потенциала пожилых людей. 
На наш взгляд, на выборе и реализации практик социального поведения пожилых людей особенно сказываются социокультурные факторы - такие как наличие образования (наиболее значимый фактор), самооценка здоровья, возможности социальной защиты и участия общества в решении социальных проблем, которые, в свою очередь, определяют социальные ресурсы, необходимые для формирования социального капитала людей этой возрастной категории.

Представленный выше анализ позволил сделать вывод, что в зависимости от характера социальной активности, индивидуальных особенностей, потребностей и мотивов поведения людей старшего возраста, внешних и внутренних факторов социальной среды, практики социального поведения пенсионеров подразделяются на активные и пассивные. В рамках активных практик следует выделить конструктивные и реактивные.

Реализация конструктивных практик поведения предполагает, что пожилой человек преследует две взаимодополняющие цели. Первая - воздействовать на социальную среду, доминировать над ней, что проявляется в творческой активности и поиске новых форм (расширении границ) социального взаимодействия, в том числе с учетом осознания возможных негативных изменений в будущем. Вторая сохранить социальную активность, не менять привычный образ, стиль жизни.

Реактивные практики проявляются в стремлении пожилого человека компенсировать потери и уменьшить ущерб от наступления пенсионного возраста - нового этапа в жизни, который связан со снижением уровня материального благосостояния. В данном случае доминирующая роль принадлежит воздействию социальной среды. Пожилой человек меняет свой образ и стиль жизни, идет на уступки социальной среде, обстоятельствам, то есть меняет себя, свое поведение в условиях стандартной ситуации на основе прошлого опыта - это привычная реакция на происходящие события.

О выборе пассивных практик свидетельствует конформное поведение пожилого человека. Они проявляются в двух видах: иждивенчество (ожидание помощи от государства, общества, родных и близких) и уклонение (проявление активности в других сферах жизни).

\section{Анализ наиболее распространенных практик поведения пожилых людей, направленных на повышение своего благосостояния}

С целью количественной оценки степени распространенности среди пожилых людей различных типов практик поведения, направленных на повышение своего благосостояния, сгруппированных в зависимости от характера социальной активности, проведен многомерный анализ результатов авторских эмпирических исследований: «Направления социальной активности пожилых людей в процессе социальной адаптации" (2018-2019 гг., N=1120); “Востребованность представителей старшего поколения на рынке труда" (2018 г., $N=268$ ).

Проведенные исследования позволили выявить следующие практики, направленные на повышение своего благосостояния (помимо оформления и получения пенсии по старости): трудовая деятельность, финансовое поведение, ведение натурального хозяйства с целью получения дополнительного дохода. Наиболее распространенная практика поведения - трудовая деятельность, ею заняты 
42,2\% респондентов. Под финансовым поведением пожилых людей в рамках нашего исследования мы понимаем использование услуг финансово-кредитных, страховых организаций, оформление и получение льгот, субсидий. Финансовое поведение наблюдается у 27,9\% пенсионеров. Ведение натурального хозяйства с целью получения дополнительного дохода характерно для 9,1\% респондентов. Далее представлен детальный анализ каждой из указанных практик поведения.

\section{Трудовая деятельность пожилых людей}

Важную роль в повышении/сохранении благосостояния пожилых людей играет трудовая деятельность и востребованность на рынке труда. Уровень трудовой занятости пенсионеров составляет 42,2\%, среди них подавляющее большинство продолжает работать на условиях полной занятости (66,7\% респондентов), занятость остальных носит временный, случайный, неформальный характер. Важно отметить, что не все люди старшего возраста, желающие работать, имеют такую возможность. Среди неработающих пенсионеров каждый третий заявил о желании трудиться (см. рис. 1). Наиболее предпочтительна для них работа, связанная с выращиванием цветов, растений, рассады (10,7\% респондентов); на дому в качестве диспетчера на телефоне (5,7\%); с чужими детьми в качестве няни, репетитора, гувернантки и т.д. $(4,4 \%)$ и оказание услуг по ремонту и пошиву одежды (3,8\%). Совершенно не интересует трудовая занятость, связанная с обработкой информации, с использованием компьютера, оргтехники, современных средств связи и коммуникаций.

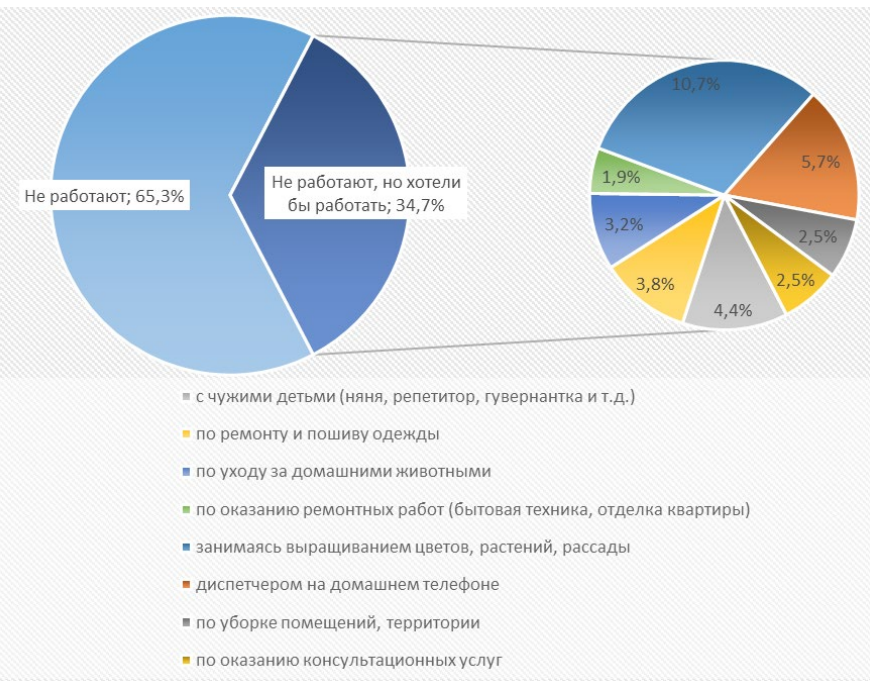

Рис. 1. Потребность, неработающих пожилых людей в трудовой занятости (в \% от числа опрошенных, $N=1120$ )

В этой связи важна оценка уровня востребованности пожилых людей на рынке труда с позиции работодателей. Согласно результатам авторских исследований (респонденты могли выбрать несколько вариантов ответов), 59,7 \% работодателей считают, что опыт и навыки людей старшего возраста незаменимы и у них есть 
чему поучиться, 41,8\% уверены, что пожилые люди незаменимы как наставники для молодежи, 33,2\% придерживаются мнения, что необходимо использовать трудовой потенциал пенсионеров, так как это дает возможность передавать профессиональный опыт молодым работникам. Каждый четвертый уверен, что пожилым подходит любая работа и возраст не имеет значения.

Главные причины, побуждающие пожилых людей продолжать трудовую деятельность после наступления пенсионного возраста, заниматься поиском подработок и т. д.,- материальные. Во-первых, недостаточный размер пенсии и стремление получать дополнительный доход к пенсии. Размер пенсии в качестве причины указывают 76,9\% пожилых людей, занятых неформальной, временной, случайной работой и 68,4\% пенсионеров, имеющих постоянную занятость. Стремление получать дополнительный доход к пенсии - 50,2\% и 35,9\% респондентов соответственно. Как мы видим, в большей степени это проявляется у тех, кто занят неформальной, временной, случайной работой. Во-вторых, стремление материально помогать детям и внукам (41,2\% респондентов). В-третьих, каждым четвертым работающим пожилым человеком руководит желание оставаться в коллективе, интерес к работе, привычка работать.

Результаты исследования показали, что работодатели полностью осознают реальные причины, побуждающие пенсионеров работать, и многие из них создают соответствующие условия, не препятствуя продолжению трудовой деятельности. Однако, принимая во внимание ценность опыта пожилых людей, практически каждый второй работодатель уверен, что они должны прислушиваться к голосу разума и вовремя уходить на пенсию, если это необходимо для организации.

По мнению работодателей (респонденты могли указывать несколько вариантов ответов), основной причиной, препятствующей трудовой занятости пожилых людей, является их состояние здоровья (39,2\% респондентов). Вторая по значимости причина - сложность в выстраивании отношений между молодым руководителем и пожилым подчиненным (25,3\%). Фактором, сдерживающим трудовую занятость, также служат некоторые личностные особенности людей этой возрастной категории. Среди них недостаток знаний в области компьютерных технологий (48,9\% респондентов-работодателей), трудности в перестройке восприятия и представлений в изменяющихся условиях (35,8\%), консерватизм (19,2\%), неспособность приспособиться к новым людям или к новой обстановке $(18,7 \%)$. В то же время, по мнению самих пожилых людей (респонденты также могли выбрать несколько вариантов ответов), помимо состояния здоровья, главные проблемы, сдерживающих их занятость, - неразвитость системы трудоустройства пенсионеров (42,3\% респондентов), их приверженность определенным нормам, принципам, убеждениям, которыми трудно, а иногда и невозможно поступиться (21,6\%), низкий уровень доверия к работодателям (19,6\%), недостаточное количество или отсутствие специализированных курсов обучения, переобучения, переквалификации и т. п. для этой возрастной категории (14,4\%).

В связи с полученными результатами вполне логичной выглядит убежденность работодателей в том, что наиболее подходящие виды занятости для пенсионеров - это работа в режиме неполного, гибкого рабочего времени (39,6\% респондентов), работа консультационного характера, оплачиваемая по факту $(20,1 \%)$, деятельность 
по ведению домашнего хозяйства с возможностью извлечения дохода (18,3\%), надомная работа (17,2\%). Каждый четвертый работодатель уверен, что для пожилых людей подходит любая работа и возраст не имеет значения (см. рис. 2).

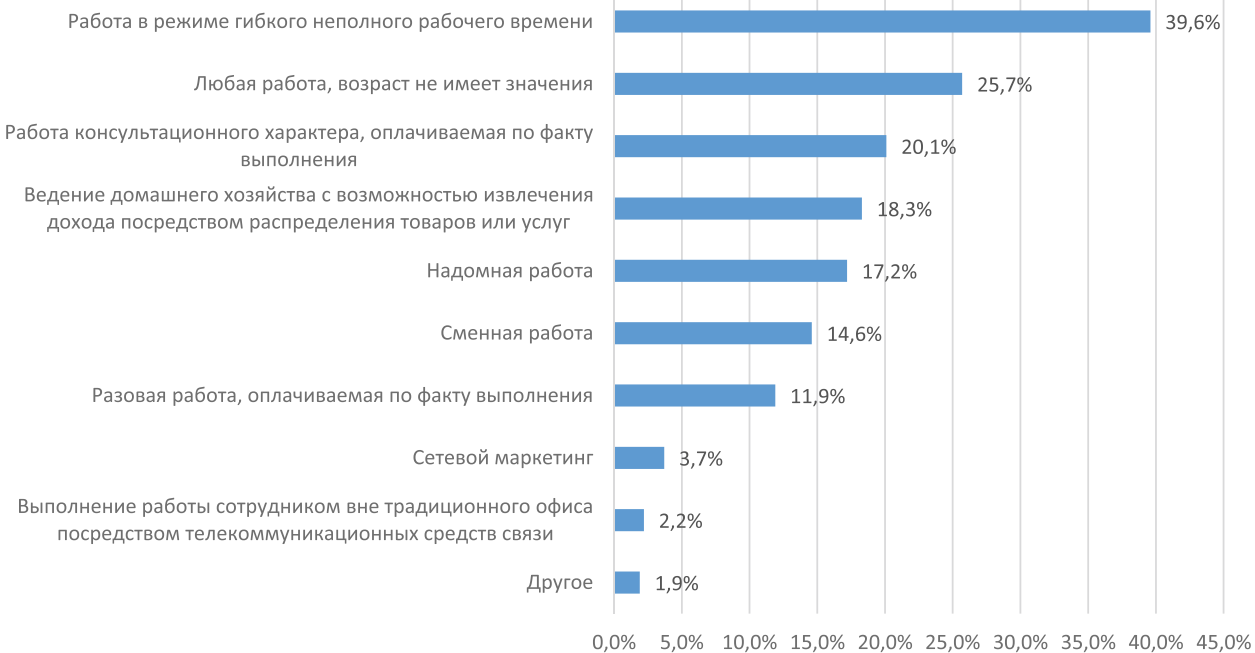

Рис. 2. Наиболее подходящая работа для пожилых людей по мнению работодателей (в \% от числа опрошенных, $N=268)^{1}$

Таким образом, в современных условиях возможность трудовой занятости пожилых людей, их стремление остаться в профессии, предопределяется как уровнем человеческого капитала пожилого человека и главными его компонентами - состоянием здоровья и профессиональными уровнем, так и стремлением, и способностью к его увеличению. Учитывая темпы цифровизации и информатизации всех без исключения сфер жизни общества, одно из направлений наращения человеческого капитала пожилых людей - освоение и внедрение в практику информационных технологий.

\section{Финансовое поведение пожилых людей}

Исследование финансового поведения пожилых людей предполагает выявление уровня финансовой грамотности. Результаты исследования показали низкую самооценку пожилыми людьми уровня финансовой грамотности. Только 11,8\% респондентов охарактеризовали свои финансовые навыки как "хорошие", 49,8\% считают себя финансово неграмотными, оставшиеся 38,4 \% назвали свои финансовые навыки удовлетворительными. На уровень финансовой грамотности значительное влияние оказывают уровень образования и профессиональный статус до наступления пенсионного возраста (80,2\% респондентов, считающих себя финансово грамотными, имеют уровень образования не ниже высшего

\footnotetext{
1 Сумма ответов больше $100 \%$, так как вопрос многовариантный.
} 
и до наступления пенсионного возраста либо занимали руководящую должность, либо работали специалистами, служащими).

В рамках финансового поведения результаты исследования позволили выделить следующие варианты: 20,4\% респондентов пользуются услугами финансовокредитных организаций (среди них 94,6\% имеют вклады в банках, 33,7 \% оформляли потребительские кредиты, 21,9\% осуществляли денежные переводы, 6,2\% оформляли кредитные карты); 9,1\% используют услуги страховых организаций (страхование имущества и жизни); 14,6\% оформляют и получают льготы, субсидии.

Анализ различных вариантов финансового поведения пожилых людей позволил выявить, что с повышением возраста увеличивается активность оформления льгот и субсидий. Это объясняется тем, что чем больше возраст, тем больше льгот и субсидий предоставляет государство (до 65 лет пользуются льготами и субсидиями 16,9\% респондентов, а в возрасте старше 80 лет-33,3\%). В то же время другие направления в рамках финансового поведения имеют противоположную тенденцию в зависимости от возраста.

\section{Ведение натурального хозяйства с целью получения дополнительного дохода}

Ведение натурального хозяйства с целью получения дополнительного дохода характерно для 9,1\% респондентов. Данная практика поведения, направленная на повышение своего благосостояния, присуща пожилым людям, проживающим в сельской местности. Среди пенсионеров, ведущих натуральное хозяйство с целью получения дополнительного дохода, 48,2\% респондентов проживают в поселках, деревнях, селах. На актуальность этого вида практики существенное влияние оказывает возраст: люди старше 70 лет в три раза реже прибегают к ней, поскольку ведение подсобного хозяйства предполагает удовлетворительное состояние здоровья, а по объективным причинам с возрастом этот показатель ухудшается.

Следует отметить, что выбор этой практики не всегда основывается на накопленном образовательном капитале. По результатам исследования, среди пожилых людей, ведущих подсобное хозяйство с целью получения дополнительного дохода, только 29,6\% респондентов имеют высшее образование.

Ведение подсобного хозяйства для 59,3\% респондентов дает возможность не только получать дополнительный доход к пенсии, но и оказывать материальную поддержку детям и внукам. В свою очередь, каждый второй пожилой человек из данной группы ждет поддержки от детей и внуков в виде помощи в устройстве быта.

Анализ практик поведения пожилых людей, направленных на повышение благосостояния, в соответствии с предложенной типологией, основанной на характере социальной активности, показал, что 65,9\% пожилых людей выбирают и реализуют активный тип практик поведения, а 34,1\% - пассивный. Высокий уровень социальной активности объясняется рядом причин: низкий размер пенсии (76,9\% респондентов), необходимость оказания материальной помощи детям и внукам (44,1\% респондентов), возможность получить дополнительный доход или льготы (39,3\% респондентов), стремление иметь сбережения (19,4\%), желание быть востребованным, независимо от возраста (18,1\% респондентов). На основе анализа причин, стимулирующих социальную активность, установлено, что актив- 
ные практики поведения подразделяются на реактивные (54,8\% респондентов) и конструктивные (11,1\% респондентов), а пассивные - на иждивенчество (4,5\% респондентов) и уклонение (29,6\% респондентов).

Также установлено, что уровень активности у пожилых людей, направленной на повышение благосостояния, неодинаков. Помимо получения пенсии по старости, 47,9\% респондентов проявляют активность, выбирая и реализуя еще хотя бы одну практику поведения из числа рассмотренных выше, а 14,7 \% - две и более. Наиболее распространенное сочетание - трудовая занятость и финансовое поведение (10,8\% респондентов совмещают данные типы поведения), а наименее распространенное сочетание - финансовое поведение и ведение натурального хозяйства с целью получения дополнительного дохода (1,1\% совмещают данные типы поведения). Следовательно, практически для каждого второго пожилого человека (47,9\% респондентов) характерен высокий уровень активности социального поведения, направленного на повышение своего благосостояния.

\title{
Факторы, влияющие на выбор и реализацию пожилыми людьми практик поведения, направленных на повышение своего благосостояния
}

Уровень активности социального поведения пожилых людей, направленной на повышение своего благосостояния, то есть совмещение нескольких практик поведения, зависит как от объективных, так и субъективных факторов, среди которых значимы место жительство, уровень образования, профессиональный статус до выхода на пенсию, состояние здоровья, удовлетворенность жизнью, уровень жизни.

другой город области

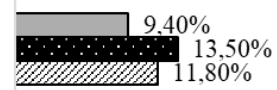

поселок, деревня, село

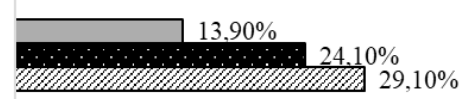

районный центр

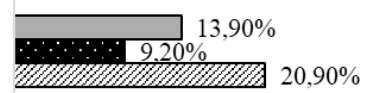

областной центр

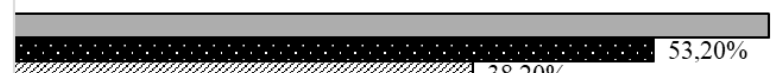

$62,80 \%$

\#WWWWWWWWWWWWW $38,20 \%$

\begin{abstract}
口получают пенсию по старости и совмещают более 2 практик поведения
- получают пенсию по старости и совмещают с еще 1 практикой поведения

च только получают пенсию по старости
\end{abstract}

Рис. З. Активность пожилых людей в зависимости от места жительства (в \% от числа опрошенных, $N=1120$ )

Как показало исследование, место жительства пожилого человека предопределяет возможность выбора той или иной практики поведения, а также совмещение нескольких. Среди пенсионеров, совмещающих более двух практик поведения, 
$62,8 \%$, проживают в областном центре, 23,3\% - в районных центрах и малых городах, 13,9\% - в поселках, селах, деревнях. А среди пожилых людей, получающих только пенсию по старости, 38,2\% проживают в областном центре, 32,7\% - в районных центрах и малых городах, 29,1\% - в поселках, селах, деревнях (см. рис. 3).

Активность пожилых людей напрямую зависит от двух взаимосвязанных факторов: уровня образования и профессионального статуса до наступления пенсионного возраста. Результаты исследования позволили установить, что бывшие руководители и пожилые люди, имеющие высшее образование, более активны (см. рис. 4).

Ученая степень $\frac{2,3 \%}{0,0 \%} 3,6 \%$

Высшее

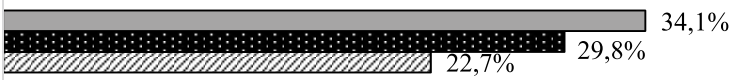

Неполное высшее

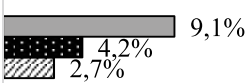

Среднее

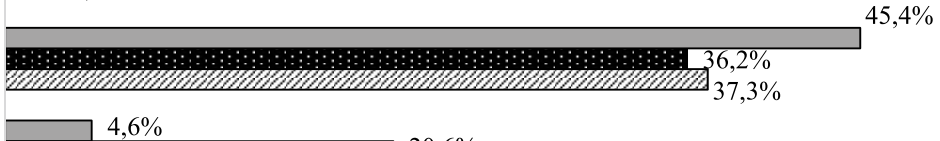

Среднее

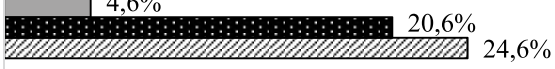

Неполное среднее

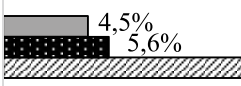

$12,7 \%$

Занимал руководящую должность

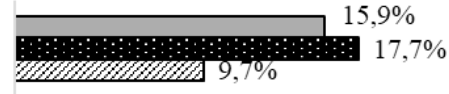

Был служащим

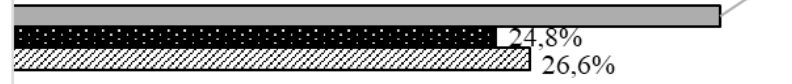

Был по роду деятельности специалистом

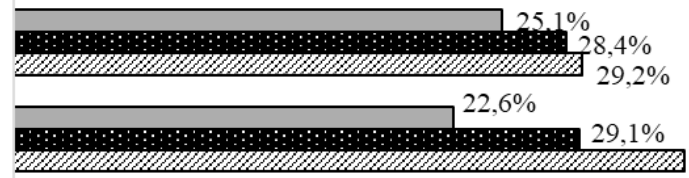

Был рабочим

口 получают пенсию по страсти и совмещают балее 2 практик поведения

- получают пенсию по старости и совмещают с еще 1 практикой поведения

च талько получают пенсию по старости

Рис. 4. Активность пожилых людей в зависимости от уровня образования и профессионального статуса до наступления пенсионного возраста (в \% от числа опрошенных, $N=1120$ )

Состояние здоровья является ключевым фактором социальной активности пенсионеров во всех без исключения сферах жизни общества. Пожилые люди, совмещающие одновременно несколько практик поведения, более оптимистично оценивают состояние своего здоровья, чем те, кто пассивен и ограничивается 
только получением пенсии по старости. Так, совмещающие несколько практик поведения, в большинстве своем, оценивают состояние своего здоровья как "удовлетворительное", "соответствующее возрасту" и "хорошее" (39,5\%, 23,4\% и 13,9\% респондентов соответственно). В то же время пожилые люди, получающие только пенсию по старости, отмечают, что их состояние здоровья "соответствует возрасту", "плохое" и "неудовлетворительное" (41,3\%, 20,2\% и 13,8\% респондентов соответственно) (см. рис. 5).

Плохое, мешает полноценной жизни

Неудовлетворительное

Соответствует моему возрасту
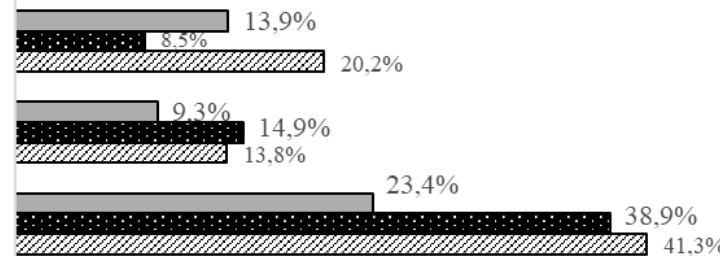

Удовлетворительное

Хорошеe

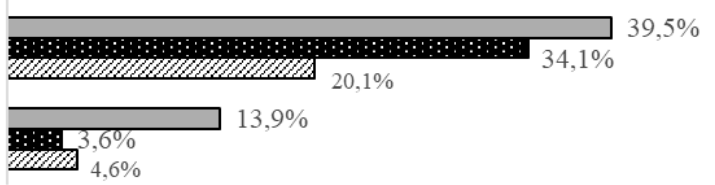

口получают пенсию по страсти и совмещают более 2 практик поведения

- получают пенсию по старости и совмещают с еще 1 практикой поведения

च только получают пенсию по старости

Рис. 5. Активность пожилых людей в зависимости от самооценки состояния здоровья (в \% от числа опрошенных, $N=1120$ )

Анализ таких влияющих на социальную активность пожилых людей факторов, как уровень образования и состояние здоровья, позволяет сделать вывод, что чем выше уровень человеческого капитала, тем активнее пожилые люди и тем больше их человеческий потенциал востребован обществом и экономикой страны. Однако следует подчеркнуть, что состояние здоровья является мощным ограничителем уровня активности пожилых людей. Например, обладая высоким уровнем образования и высоким профессиональным статусом до наступления пенсионного возраста, но имея неудовлетворительное состояние здоровья, пожилой человек автоматически лишается возможности продолжать трудовую деятельность, заниматься натуральным хозяйством с целью получения дополнительного дохода и т.д.

Сопоставление уровня активности и самооценки уровня жизни позволило на основе полученных результатов исследования прийти к следующим выводам (см. рис. 6). Во-первых, пожилые люди, живущие в полном достатке, выйдя на пенсию, в большинстве своем ориентированы на социальную активность в других сферах общественной жизни, а в плане повышения своего благосостояния ограничиваются только получением пенсии (20,9\% респондентов). Во-вторых, совмещая различные практики поведения, направленные на повышение своего благосостояния (хотя бы еще одну в дополнение к получению пенсии по старости), большинство пожилых людей стремятся улучшить уровень жизни за счет получения дополнительного дохода к пенсии (42,1\% респондентов, оценивающих свой уро- 
вень жизни как "живу сносно" и 26,4\% - "живу от пенсии до пенсии"). В-третьих, низкий уровень активности в сочетании с низкой самооценкой уровня жизни характерен для пожилых людей с невысоким уровнем человеческого капитала. Среди них большинство имеет плохое состояние здоровья (62,5\% респондентов оценили свое состояние здоровья как "плохое, мешающее полноценной жизни" и 25,1\% - как «неудовлетворительное»), и уровень образования у этих респондентов не превышает среднего специального (84,9\% респондентов).

Живу в полном достатке

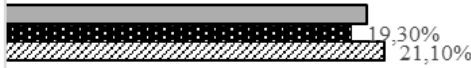

Живу сносно

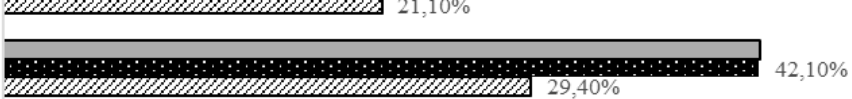

Живу от пенсии до пенсии

Не свожу концы с концами

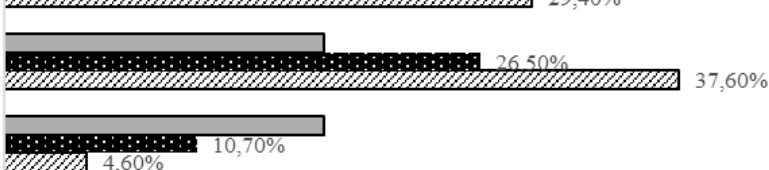

Живу в нищете

Ваш вариант (напишите)

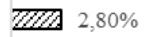

口получают пенсию по страсти и совмещают более 2 практик поведения

- получают пенсию по старости и совмещают с еще 1 практикой поведения

$\boldsymbol{\boldsymbol { D }}$ только получают пенсию по старости

Рис. 6. Активность пожилых людей в зависимости от самооценки уровня жизни (в процентах от числа опрошенных $N=1120$ )

Рассмотренные факторы оказывают постоянное прямое воздействие на выбор и реализацию пенсионерами практик поведения, направленных на повышение своего благосостояния. В свою очередь, и пожилые люди способны воздействовать на них. Следовательно, такие факторы, как уровень образования, профессиональный статус до наступления пенсионного возраста, состояние здоровья, самооценка уровня жизни, удовлетворенность жизнью и т. д., следует считать личностными. Все личностные факторы взаимосвязаны, и изменение одного из них влияет на другие.

В то же время пожилые люди вовлечены в социальные взаимодействия в условиях определенной социальной среды, которая также влияет на выбор и реализацию практик поведения. К факторам социальной среды относятся: реализуемая социальная политика в отношении пожилых людей, доступность социальных услуг, пенсионное обеспечение, востребованность профессионального, социального, интеллектуального, человеческого потенциала пожилых людей, существующие стереотипы и т.д. Факторы социальной среды следует рассматривать на макроуровне (уровне государства) и мезоуровне (уровне отдельного региона), что даст возможность выявить региональную специфику.

На наш взгляд, анализ факторов социальной среды в современных российских условиях следует сконцентрировать на рассмотрении вопросов активного долголетия и реформирования пенсионной системы. 
Впервые понятие «активное долголетие» было сформулировано Всемирной организацией здравоохранения (BO3) в 2002 г. в Рамочной стратегии активного долголетия B03. Согласно данному там определению активное долголетие представляет собой процесс оптимизации возможностей в области здоровья, участия и безопасности с целью повысить качество жизни по мере старения [World Healh Organisation, 2002].

5 февраля 2016 г. в Российской Федерации на государственном уровне была принята “Стратегия действий в интересах граждан старшего поколения в Российской Федерации до 2025 г.", интегрировавшая концепцию активного долголетия. Ожидаемым результатом реализации этой стратегии является создание условий для активного долголетия, которые позволят повысить уровень и качество жизни граждан старшего поколения ${ }^{2}$. Принятие стратегии свидетельствует о том, что на уровне государства пересмотрено отношение к пожилым людям как к объектам заботы, помощи, клиентам социальных учреждений, нуждающимся в опеке и т. п., и поставлена задача предоставить пенсионерам возможность самостоятельно принимать решения, что, как и когда делать. Это должно способствовать раскрытию их потенциала. Также вопросы активного долголетия отражены в таких нормативных документах Российской Федерации, как Национальный проект "Демография" 2019-2024 гг. и Федеральный проект разработки и реализации программы системной поддержки и повышения качества жизни граждан старшего поколения "Старшее поколение" 2019-2024 гг. В сентябре 2019 г. на заседании Совета при Правительстве Российской Федерации по вопросам попечительства в социальной сфере под председательством заместителя председателя Правительства Т. А. Голиковой прошло обсуждение Проекта концепции “Активное долголетие в Российской Федерации", подготовленной мультидисциплинарной и межведомственной рабочей группой на базе НИУ ВШЭ [Овчарова, Морозова, Синявская, 2020]. Концепция политики активного долголетия разработана в соответствии с основными российскими и международными нормативными и стратегическими документами. Проект Концепции содержит ключевые понятия, основополагающие принципы политики активного долголетия и предложения по направлениям развития этой политики, сгруппированные в три базовых приоритета: здоровье граждан старшего поколения, обеспеченная и достойная жизнь в старшем возрасте, активность и участие в жизни общества.

Однако, как отмечают занимающиеся проблемами старения населения известные социологи И. А. Григорьева и Е.А Богданова (и с ними сложно не согласиться), несмотря на то, что концепция политически продвигается, на сегодняшний день она плохо сочетается с инфраструктурной поддержкой пожилых людей; на государственном уровне слабо просматривается связь основных положений активного старения с положениями государственной социальной политики (нет прорывов в технологиях профилактики старения или длительного ухода); подходы и технологии работы с пожилыми людьми, реализуемые учреждениями социального обслуживания, не корректируются с учетом национальных планов по демографии [Григорьева, Богданова, 2020]. Следует подчеркнуть, что к причинам, сдержи-

\footnotetext{
2 Распоряжение Правительства Российской Федерации от 05.02.2016 г. № 164-р «Об утверждении Стратегии действий в интересах граждан старшего поколения в Российской Федерации до 2025 года" //Собрание законодательства РФ. 2016. 15 февраля. № 7. Ст. 1017.
} 
вающим развитие активного долголетия в России, относятся состояние здоровья и низкая продолжительность жизни пожилых людей, неразвитость инфраструктуры для добровольческой и общественной деятельности, образования, физической активности этой возрастной категории и т. п.

Обращает на себя внимание тот факт, что при построении и реализации социальной политики в отношении пожилых людей в России за основу взята уверенность в том, что с увеличением возраста у пенсионеров сокращаются потребности. А это, в свою очередь, является причиной появления оснований социального неравенства и, как следствие, приводит к социальной эксклюзии во всех сферах общества, потере смысла жизни в пожилом возрасте, в то время как в европейских странах акцент сделан на индивидуальную ответственность за состояние здоровья, стимулирование трудовой занятости и недопущение социального исключения.

Реформирование пенсионной системы в России, а именно повышение пенсионного возраста, затронуло значительную часть населения страны и стало беспрецедентным за последние почти 90 лет. В настоящее время повышение пенсионного возраста рассматривается как общемировая тенденция, происходящая во всех государствах.

Следует отметить, что объективные причины повышения пенсионного возраста в России такие:

- увеличение демографической нагрузки на трудоспособное население, то есть изменение соотношения между числом граждан трудоспособного возраста и числом граждан, достигших пенсионного возраста (на начало 2002 г. на 1000 лиц трудоспособного возраста приходилось 335 человек старше трудоспособного возраста, на начало 2020 г.- 443 человека, а по самым оптимистичным прогнозам Федеральной службы государственной статистики на 2031 г.-508 человек), что приводит к разбалансировке пенсионной системы, так как в России реализуется пенсионная система, предполагающая, что источником выплаты пенсий являются страховые взносы работающих;

- повышение стабильности и финансовой устойчивости пенсионной системы как источника достойного уровня пенсий пожилых людей;

- увеличение времени на получение образования, что сокращает период трудовой занятости до наступления пенсионного возраста;

- изменения в условиях и характере трудовой занятости - труд становится физически более легким, увеличивается число занятых с высоким уровнем квалификации, растет занятость в сфере услуг, здравоохранении, образовании;

- высокий уровень занятости населения в возрасте старше трудоспособного (в 2019 г. он составил 21,3\%);

- улучшение состояния здоровья и увеличение продолжительности жизни (в 1961-1962 гг. продолжительность жизни составляла 63,78 лет у мужчин, у женщин - 72,38 лет, в 2019 г.-68,24 лет и 78,17 лет соответственно) [Баранов, Скуфьина, Гущина, 2020; Бобков, Забелина, Локтюхина, 2015; Гринберг, Сафонов, 2019].

Повышение пенсионного возраста неизбежно оказывает влияние на рынок труда, систему социально-трудовых отношений, систему социального и пенсионного обеспечения, уровень и качество жизни населения. Исследования отечественных ученых показывают, что повышение пенсионного возраста в России имеет и будет иметь положительные и отрицательные последствия [Бобков, Забелина, 
Локтюхина, 2015; Соловьев, 2019; Чичканов и др., 2018]. Среди положительных следует отметить: обеспечение потребностей экономики в профессиональных кадрах; формирование конкурентного рынка труда, на котором конкурентными преимуществами работника являются знания, навыки, гибкость и адаптивность, а не имеющийся статус занятости; снижение масштабов неформальной занятости и различных форм неустойчивой занятости; создание юридических рамок для сохранения занятости высококвалифицированных рабочих старшего поколения. В то же время отрицательные последствия связаны с ростом уровня безработицы из-за низкой конкурентоспособности пожилых людей на рынке труда; снижением качества рабочей силы за счет дополнительного притока на рынок труда лиц старшего возраста оттоком лиц этой возрастной категории из бюджетной сферы.

Особняком стоит и проблема замещения социальных функций, выполняемых пожилыми людьми. Повышение пенсионного возраста вынуждает людей, достигших возраста 55(60), лет менять свои планы и продолжать работать еще в среднем пять лет, лишаясь права выбора продолжать трудовую деятельность или заняться чем-то другим. Помимо этого, изменения затронут и других членов семей, поскольку значительная часть выходивших на пенсию в 55(60) лет выполняла важные социальные функци, такие как уход за нетрудоспособными членами семьи, что снижало нагрузку на систему социальной защиты; воспитание внуков, что создавало условия для занятости родителей.

Также следует отметить, что повышение пенсионного возраста лишает пенсионных выплат минимум за полгода - максимум за пять лет, которые раньше полагались при наступлении возраста 55(60) лет и на которые люди рассчитывали. Данная ситуация может быть воспринята как проявление социальной несправедливости и сказаться на отношении людей к власти.

Перечисленные проблемы и последствия повышения пенсионного возраста проявляются в социальном недовольстве россиян, усилении чувства социальной несправедливости. На наш взгляд, такая реакция общества спровоцирована недостаточным уровнем информирования населения о новых возрастных границах, этапах повышения пенсионного возраста, о льготах и социальной поддержке людей, попавших в группу предпенсионеров. В настоящее время ситуация усугубляется экономическим кризисом, спровоцированным пандемией коронавируса, при котором возрастают риски потери работы, сокращения размера заработной платы.

Однако на государственном уровне усилено внимание к социально-экономическим потребностям пожилых людей, проблемам трудоустройства и сохранения занятости, что послужило толчком к развитию программ активного долголетия, совершенствованию социальной политики, сохранению человеческого потенциала и преодолению устоявшихся стереотипов в отношении пожилых людей.

\section{Заключение}

Обобщение результатов оригинального социологического исследования, анализ вторичной научной информации позволили выделить ряд положений, имеющих новизну в изучении проблематики активного долголетия, образа и стиля жизни пожилых людей в современном российском обществе. Во-первых, пожилые люди являются активными участниками социального взаимодействия 
в социально-экономической сфере. Однако это взаимодействие в основном носит вынужденный характер и связано с улучшением/сохранением своего благосостояния, то есть является реакцией на ту социальную реальность, в которую они попадают в связи с выходом на пенсию и переходом в новую для себя социальную группу пожилых людей. Согласно предложенной типологии практик социального поведения, 65,9\% пожилых людей выбирают и реализуют активный тип практик, в том числе 54,8\% придерживаются реактивного типа, 11,1\% - конструктивного.

Во-вторых, помимо получения пенсии по достижении пенсионного возраста, наиболее распространенными практиками поведения пожилых людей, направленными на повышение своего благосостояния, являются трудовая деятельность (42,2\% респондентов), финансовое поведение $(27,9 \%)$, ведение натурального хозяйства с целью получения дополнительного дохода $(9,1 \%)$.

В-третьих, уровень активности пожилых людей в направлении повышения своего благосостояния неодинаков и определяется количеством одновременно выбранных и реализуемых практик поведения. Так, 47,9\% респондентов проявляют активность, выбирая и реализуя еще хотя бы одну практику поведения в дополнение к получению назначенной пенсии, а 14,7\% респондентов - две и более.

В-четвертых, на выбор и реализацию практик поведения, направленных на повышение своего благосостояния, стимулирующее и сдерживающее воздействие оказывает ряд факторов, как внешних по отношению к пожилому человеку (социальная среда), так и личностных - зависящих от самого человека. Определяющее значение имеют такие факторы, как уровень образования, состояние здоровья, место жительства, самооценка уровня жизни, социально-профессиональный статус до наступления пенсионного возраста, востребованность накопленного потенциала пожилых людей социальной средой, что свидетельствует о том, что «беловоротничковая занятость" и высшее образование дают преимущества не только в период трудоустройства, но и формируют различные возможности после выхода на пенсию. В настоящее время существенное влияние на социальное поведение пожилых людей оказывает политика государства в части реализации стратегии активного долголетия и реформирования пенсионной системы.

В качестве перспектив изучения темы предлагается, во-первых, исследование практик социального поведения пожилых людей, направленных на повышение своего благосостояния, на более широком эмпирическом материале, а именно исследование и сравнительный анализ практик в регионах с разным уровнем социального-экономического развития. Во-вторых, выделение различных групп пожилых людей, которым оказываются доступны разнообразные практики поведения, в зависимости от имеющихся у них возможностей и ограничений.

\section{Список литературы (References)}

Баранов С. В., Скуфьина Т. П., Гущина И. А. Влияние повышения пенсионного возраста на экономику и настроения населения Мурманской области // Экономические и социальные перемены: факты, тенденции, прогноз. 2020. Т. 13. № 1. С. 160173. https://doi.org/10.15838/esc.2020.1.67.9. 
Baranov S. V., Skufina T. P., Gushchina I. A. (2020) The Impact of the Retirement Age Increase on the Economy and Attitudes of the Population of the Murmansk Oblast. Economic and Social Changes: Facts, Trends, Forecast. Vol. 13. No. 1. P. 160-173. https://doi.org/10.15838/esc.2020.1.67.9. (In Russ.)

Бобков В.Н., Забелина О.В., Локтюхина Н.В. Повышение пенсионного возраста в Российской Федерации: социально-трудовые последствия // Народонаселение. 2015. № 4. C. 93-107. URL: http://www.isesp-ras.ru/numbers/2015-4 (дата обращения: 06.04.2021).

Bobkov V. N., Zabelina O. V., Loktyukhina N. V. (2015) Raising the Retirement Age in the Russian Federation: Social and Labour Consequences. Population. No. 4. P. 93-107. URL: http://www.isesp-ras.ru/numbers/2015-4 (accessed: 06.04.2021). (In Russ.)

Вебер М. Избранные произведения. М.: Наука, 1990.

Weber M. (1990) Selected Works. Moscow: Nauka. (In Russ.)

Григорьева И. А., Парфенова О. А., Петухова И. С. Занятость и социальное исключение пожилых граждан (обзор европейских конференций) // Социологические исследования. 2018. № 5. С. 157-159. https://doi.org/10.7868/S013216251805015X. Grigorieva I.A., Parfenova O.A., Petukhova I.S. (2018) Employment and Social Exclusion of Senior Citizens (Review of European Conferences). Sociological Studies. No. 5. P. 157-159. https://doi.org/10.7868/S013216251805015X. (InRuss.)

Григорьева И. А., Богданова Е. А. Концепция активного старения в Европе и России перед лицом пандемии COVID-19 // Laboratorium: журнал социальных исследований. 2020. Т. 12. № 2. С. 187-211. https://doi.org/10.25285/2078-19382020-12-2-187-211.

Grigoryeva I. A., Bogdanova E. A. (2020) The Concept of Active Aging in Europe and Russia in the Face of the COVID-19 Pandemic. Laboratorium: Russian Review of Social Research. Vol. 12. No. 2. P. 187-211. https://doi.org/10.25285/2078-1938-202012-2-187-211. (In Russ.)

Григорьева И.А., Видясова Л. А., Дмитриева А. В., Сергеева О.В. Пожилые в современной России: между занятостью, образованием и здоровьем. СПб. :Алетейя, 2015. Grigorieva I. A., Vidyasova L. A., Dmitrieva A. V., Sergeeva O. V. (2015) Elderly in Modern Russia: Between Employment, Education and Health. St. Petersburg: Aletheya. (In Russ.)

Гринберг Р. С., Сафонов А. Л. Повышение пенсионного возраста в России, или Как бюджетная мифология усугубляет социальное неблагополучие страны //Журнал новой экономической ассоциации. 2019. № 2. С. 167-176. https://doi.org/10.31737/ 2221-2264-2019-42-2-9.

Grinberg R. S., Safonov A. L. (2019). Raising the Retirement Age in Russia, or How Budget Mythology Exacerbates the Social Disadvantage of the Country. Journal of the New Economic Association. No. 2. P. 167-177. https://doi.org/10.31737/22212264-2019-42-2-9. (In Russ.)

Елютина М. Э., Болотов Г.И. Повседневная жизнь пожилой семьи: стратегия планирования и жесткой экономии ресурсов // Известия Саратовского университета. 
Новая серия. Серия: Социология. Политология. 2017. Т. 17. № 1. С. 10-14. https:// doi.org/10.18500/1818-9601-2017-17-1-10-14.

Elyutina M. E., Bolotov G. I. (2017) Everyday Life of the Elderly Family: A Strategy for Planning and Austerity. Izvestia of Saratov University. New Series. Series: Sociology. Politology. Vol. 17. No. 1. P. 10-14. https://doi.org/10.18500/1818-9601-2017-17-1-10-14. (In Russ.)

Елютина М. Э. Социальная экзистенция старости: архив мнений. Саратов: Издательство Саратовского университета, 2017.

Eliutina M.E. (2017) Old Age Social Existence: The Archive of Opinions. Saratov: Izdatelstvo Saratovskogo universiteta. (In Russ.)

Козлова Т. З., Краснова О.В. Старшее поколение: гендерный и социальнопсихологические аспекты. Saarbrücken: Palmarium Academic Publishing, 2015. Kozlova T.Z., Krasnova O.V. (2015) The Older Generation: Gender and SocioPsychological Aspects. Saarbrücken: Palmarium Academic Publishing. (In Russ.)

Овчарова Л.Н., Морозова М.А., Синявская О.В. Концепция политики активного долголетия: научно-методологический доклад к XXI Апрельской международной научной конференции по проблемам развития экономики и общества. Национальный исследовательский университет "Высшая школа экономики". М. : Издательский дом Высшей школы экономики, 2020. URL: https://conf.hse. ru/mirror/pubs/share/360906541.pdf (дата обращения: 04.04.2021).

Ovcharova L. N., Morozova M. A., Sinyavskaya O. V. (2020) The Concept of the Policy of Active Aging: Scientific and Methodological Report for the XXI April International Scientific Conference on the Problems of Economic and Social Development. National Research University Higher School of Economics. Moscow: The Higher School of Economics Publishing House. URL: https://conf.hse.ru/mirror/pubs/ share/360906541.pdf (accessed: 04.04.2021). (In Russ.)

Корнилова М.В. Инновации и риски мониторинга уровня и качества жизни пожилых москвичей: анализ материалов фокус-дискуссии // Вестник Новосибирского государственного университета экономики и управления. 2017. № 1. С. 267-281. URL: https://nsuem.elpub.ru/jour/article/view/972 (дата обращения: 04.04.2021). Kornilova M. V. (2017) Innovations and Risks in Monitoring of Level and Quality of Life of Older Muscovites: Analysis of Materials Focus-Group Discussion. Vestnik of the Novosibirsk State University of Economics and Management. No. 1. P. 267-281. URL: https://nsuem.elpub.ru/jour/article/view/972 (accessed: 04.04.2021). (In Russ.)

Кошарная Г.Б., Щанина Е.В. Факторы депривации пожилых людей в социально-трудовой сфере: региональный аспект // Вестник Российского университета дружбы народов. Серия: Социология. 2019. Т. 19. № 3. С. 481-493. https:// doi.org/10.22363/2313-2272-2019-19-3-481-493.

Kosharnaya G. B., Shchanina E. V. (2019) Deprivation Factors for the Elderly in the Social-Labor Sphere: A Regional Aspect. RUDN Journal of Sociology. Vol. 19. No. 3. P. 481-493. https://doi.org/10.22363/2313-2272-2019-19-3-481-493. (In Russ.)

Максимова С. Г., Ноянзина О.Е., Максимова М. М., Щеглова Д. К. Социальная эксклюзия лиц старших возрастных групп: социально-экономические аспекты//Вестник 
Алтайского государственного аграрного университета. 2015. № 5. C. 180-184. URL: http://www.asau.ru/vestnik/2015/5/180-184.pdf (дата обращения: 06.04.2021). Maksimova S. G., Noyanzina O.YE., Maksimova M. M., Shcheglova D. K. (2015) Social Exclusion of Persons of Elderly Age Groups: Social-Economic Aspects. Vestnik Altaiskogo gosudarstvennogo agrarnogo universiteta. No. 5. P. 180-184. URL: http:// www.asau.ru/vestnik/2015/5/180-184.pdf (accessed: 06.04.2021). (In Russ.)

Максимова С. Г., Старчикова М.В. Методологические подходы к изучению социального механизма формирования адаптивных стратегий лиц старших возрастных групп в рамках становления новой геронтологической реальности // Известия Алтайского государственного университета. Философия, социология и культурология. 2009. № 2. С. 150-154. URL: http://izvestia.asu.ru/2009/2/soci/01.ru.html (дата обращения: 06.04.2021).

Maximova S. G., Starchikova M. V. (2009). Methodological Approaches to Studying the Social Mechanism of Formation Adaptive Strategy of Persons of the Senior Age Groups Within the Limits of Formation New Gerontology Realities. Izvestiya of Altai State University. No. 2. P 150-154. URL: http://izvestia.asu.ru/2009/2/soci/01. ru.html (accessed: 06.04.2021). (In Russ.)

Неваева Д. А., Максимова С.Г. Социальная эксклюзия пожилых людей (по материалам социологических исследований в Алтайском крае) // Социальная интеграция и развитие этнокультур в евразийском пространстве. 2016. № 4-2. С. 71 -77. Nevaeva D. A., Maksimova S. G. (2016) Social Exclusion of the Elderly (Based on the Sociological Studies in the Altai Region). Social Integration and Development of Ethnic Cultures in the Eurasian Space. No. 4-2. P. 71-77. (In Russ.)

Савинов Л.И., Кочетков С. С. Сравнительный анализ форм организации социальнодосуговой работы с пожилыми людьми // Дискуссия. 2017. № 10. C. 60-66. URL: https://www.journal-discussion.ru/vypuski-zhurnala/vypusk-nomer-84-noyabr-2017/ statya-2115 (дата обращения: 06.04.2021).

Savinov L. I., Kochetkov S. S. (2017) Comparative Analysis of the Forms of Organizing Social and Leisure Work With Elderly People. Discussion. No. 10. P. 60-66. URL: https://www.journal-discussion.ru/vypuski-zhurnala/vypusk-nomer-84-noyabr-2017/ statya-2115i (accessed: 06.04.2021). (In Russ.)

Саралиева 3.М., Балабанов С.С. Пожилой человек в Центральной России//Психология старости и старения / сост. О.В. Краснова, А. Г. Лидерс. М.:Академия, 2003. С. 91-100. Saralieva Z. M., Balobanov S.S. (2003) An Elderly Person in Central Russia. In: Krasnova O. V., Liders A. G. (eds.) Psychology of Old Age and Aging. Moscow: Academy. P. 91-100. (In Russ.)

Соловьев А. К. Социальные последствия повышения пенсионного возраста // Социологические исследования. 2019. № 3. С. 23-31. https://doi.org/10.31857/ S013216250004275-5.

Solovev A. (2019). Social Consequences of Retirement Age Raising. Sociological Studies. No. 3. P. 23-31. https://doi.org/10.31857/S013216250004275-5 (accessed: 06.04.2021). (In Russ.) 
Тощенко Ж.Т. Жизненный мир и его смыслы // Социологические исследования. 2016. № 1. C. 6-17. https://www.isras.ru/index.php?page_id=2624\&jn=socis\&jn $=$ socis\&jid=6011 (дата обращения: 06.04.2021).

Toshchenko ZH.T. (2016) Life World and Its Meanings. Sociological Studies. No. 1. P. 6-17. http://socis.isras.ru/files/File/2016/2016_1/6_17_Toshchenko.pdf (In Russ.)

Холостова Е.И. Пожилой человек в обществе. М.: Московский государственный университет сервиса, 1999.

Kholostova E. I. (1999) An Elderly Person in Society. Moscow: Moscow State University of the Service. (In Russ.)

Чичканов В.П., Чистова Е. В., Тырсин А. Н., Степанов А. Н. Последствия повышения пенсионного возраста для рынка труда регионов России // Вестник УрФУ. Серия: Экономика и управление. 2018. Т. 17. № 6. С. 1037-1055. https://doi.org/ 10.15826/vestnik.2018.17.6.047.

Chichkanov V. P., Chistova E. V., Tyrsin A. N., Stepanov A. N. (2018) The Impact of Increasing the Pension Age for Labor Market Regions of Russia. Bulletin of Ural Federal University. Series Economics and Management. Vol. 17. No. 6. P. 1037-1055. https:// doi.org/10.15826/vestnik.2018.17.6.047. (In Russ.)

Швери Р. Теоретическая социология Джеймса Коулмена: аналитический обзор // Социологический журнал. 1996. № 1-2. С. 62-81. URL: https:/ /www.jour. fnisc.ru/index.php/socjour/article/view/260 (дата обращения: 06.04.2021).

Schweri R. (1996) Theoretical Concept of James S. Coleman: an Analytical Review. Sociological Journal. No. 1-2. P. 62-81. URL: https://www.jour.fnisc.ru/index.php/ socjour/article/view/260 (accessed: 06.04.2021). (In Russ.)

Щанина Е. В. Социокультурный подход к анализу социального поведения пожилых людей / / Социально-гуманитарные знания. 2017 . № 9. С. 240-251.

Shchanina E. V. (2017) Socio-Cultural Approach to the Analysis of Social Behavior of Older People. Social and Humanitarian Knowledge. No. 9. P. 240-251. (In Russ.)

Щукина Н. П. Институт взаимопомощи в системе социальной поддержки пожилых людей. М. : Дашков и $\mathrm{K}^{\circ}, 2004$.

Shchukina N.P. (2004) Institute of Mutual Help in the System of Social Support of Old People. Moscow: Dashkov i K. (In Russ.)

Яницкий О.Н. “Турбулентные времена" как проблема общества всеобщего риска (Времена турбулентности и задачи социологии) // Общественные науки и современность. 2011. № 6. С. 155-164. URL: http://ecsocman.hse.ru/data/2014/ 01/16/1251305211/Janitsky.pdf (дата обращения: 07.04.2021).

Yanitskiy O. N. (2011) “Turbulent Times” as a Problem of Risk Society. Social Sciences and Contemporary World. No. 6. P. 155-164. URL: http://ecsocman.hse.ru/ data/2014/01/16/1251305211/Janitsky.pdf (accessed: 07.04.2021). (In Russ.)

World Healh Organisation. (2002) Active Aging: A Policy Framework. Geneva: World Healh Organisation. URL: https://www.who.int/ageing/publications/active_ageing/ en/ (accessed: 07.04.2021). 